\title{
Correction: Waldenström macroglobulinemia treatment algorithm 2018
}

Morie A. Gertz ${ }^{1}$

\section{Correction to: Blood Cancer Journal \\ https://doi.org/10.1038/s41408-018-0076-5 \\ Published online 01 May 2018}

Following the publication of this article the authors noted that the sentence on page 5 reading "The major response rate was $80 \%$ with no difference between patients with wild-type or mutated MYD 88" was incorrect, and should read as "The major response rate was $80 \%$ with no difference between patients with mild-type or mutated CXCR4". The authors wish to apologise for any inconvenience caused. This has now been corrected in the HTML and PDF.

Published online: 25 June 2019

Correspondence: Morie A. Gertz (gertz.morie@mayo.edu)

'Division of Hematology, Mayo Clinic, 200 First Street, SW, Rochester, MN

55905, USA

() The Author(s) 2019

(c) (i) Open Access This article is licensed under a Creative Commons Attribution 4.0 International License, which permits use, sharing, adaptation, distribution and reproduction cc) in any medium or format, as long as you give appropriate credit to the original author(s) and the source, provide a link to the Creative Commons license, and indicate if changes were made. The images or other third party material in this article are included in the article's Creative Commons license, unless indicated otherwise in a credit line to the material. If material is not included in the article's Creative Commons license and your intended use is not permitted by statutory regulation or exceeds the permitted use, you will need to obtain permission directly from the copyright holder. To view a copy of this license, visit http://creativecommons.org/licenses/by/4.0/. 